\title{
Soil Fertility Assessment under Different Polyhouses in Cold Arid Ladakh Region
}

\author{
Phuntsog Tundup*, Rigzin Sangdup Safal, D. Namgail, Sonam Spaldon, \\ Anwar Hussain, Deldan Namgail and Yogesh Kumar
}

SKUAST, Leh-Ladakh, India

*Corresponding author

\section{A B S T R A C T}

\section{Keywords \\ Precision farming, Soil properties, Nutrient, Correlation \\ Article Info \\ Accepted: \\ 20 January 2018 Available Online: 10 February 2018}

Twenty eight (28) soil samples from different polyhouses were collected from precision farming development Centre (PFDC) Leh, situated in the cold arid Ladakh region and were analyzed for different soil properties and its fertility status. It is apparent from the study that the majority of soils are rich in organic carbon, available nitrogen, phosphorus, potassium and sulphur and low in available zinc. Among soil properties, organic carbon content had a positive correlation on the availability of nutrients. This information can be useful in developing management practices for the soils of different poly houses at the Centre.

\section{Introduction}

Soil fertility evaluation of an area or region is an important aspect in context of sustainable agricultural production, particularly for arid region where, sparse and highly variable precipitation, extreme variation in diurnal temperature, high evaporation and low humidity, the alluvial and aeolian landforms have given rise to the variability in soils. Besides, acute moisture deficit, wind erosion is most serious limiting factor limiting biological productivity.

The region had extreme fallowing in past years. But because of increase in population and in particular for off-season production of vegetables, lots of area is being brought under poly house cultivation; even rocky barren lands are also cultivated.

In present era of technological advancement in agriculture, it is of immense interest to study the soil fertility status of these poly houses. Therefore, a comprehensive study was undertaken to know the fertility status of soils occurring in the poly houses in order to maintain optimum level of nutrients and an attempt was also made to correlate these macro and micronutrients content with other soil properties. 


\section{Materials and Methods}

\section{Description of the study area}

The study was conducted in Precision Farming Development Centre, SKUAST-K, Leh, located in the south-eastern part of Ladakh and lies between $31^{\circ} 44^{\prime} 57^{\prime \prime}$ ' to $32^{\circ} 59^{\prime} 57^{\prime \prime} \mathrm{N}$ latitude and $76^{\circ} 46^{\prime} 29^{\prime \prime}$ to $80^{\circ} 41^{\prime} 34^{\prime \prime}$ E longitude. The study area has an average annual rainfall of less than 200 $\mathrm{mm}$, while the main daily temperatures range from $-30^{\circ} \mathrm{C}$ to $+35^{\circ} \mathrm{C}$.

\section{Soil analysis}

Twenty eight (28) soil samples (two each from polyhouses) were randomly collected at 0 to $20 \mathrm{~cm}$ depth using khurpi to avoid any contamination of the soils.

The samples were air dried, ground, and passed through $2 \mathrm{~mm}$ sieve before analysis. Soil reaction of the soil samples was determined in 1: 2.5 soil: water suspension $(\mathrm{w} / \mathrm{v})$ with the help of glass electrode $\mathrm{pH}$ meter (Jackson, 1973).

Electrical conductivity was estimated in 1: 2.5 soil: water suspension with EC meter as given by Chopra and Kanwar (1991).Organic carbon was analyzed with the help of rapid titration method as proposed by Walkley and Black (1934). The available macro and micronutrients were determined in Mini soil testing kit developed by Indian institute of soil science, Bhopal.

\section{Results and Discussion}

Data on soil properties showed that the soils are marginally to strongly alkaline in reaction (pH 7.84-8.65). The electrical conductivity (EC) ranged from 395-2730 $\mu \mathrm{S} \mathrm{cm}$, the highest value $\left(2730 \mu \mathrm{S} \mathrm{cm}^{-1}\right)$ and lowest value $\left(395 \mu \mathrm{S} \mathrm{cm}^{-1}\right)$ of soil was found in Shade Net and LEHO type of poly house, respectively.
Organic carbon content varied from 0.25$2.19 \%$ with a mean value of $1.22 \%$.

The content of available $\mathrm{N}$ in soils varied from 118.75 to $481.8 \mathrm{~kg} \mathrm{ha}^{-1}$ with an average value of $338.79 \mathrm{~kg} \mathrm{ha}^{-1}$ (Table 1). Data on available $\mathrm{N}$ in soil samples indicated that four polyhouses have deficient in available $\mathrm{N}$ content, considering $<280 \mathrm{~kg} \mathrm{ha}^{-1}$ as critical limit for $\mathrm{N}$ deficiency (Muhr et al., 1965). The maximum $\left(481.8 \mathrm{~kg} \mathrm{ha}^{-1}\right)$ and minimum available $\mathrm{N}\left(118.75 \mathrm{~kg} \mathrm{ha}^{-1}\right)$ in soils was found in Mud wall II and Chinese greenhouse II, respectively. The availability of $\mathrm{N}$ increased significantly with an increase in organic carbon $\left(0.986^{* *}\right)$ (Table 2). The positive relationship between available $\mathrm{N}$ and organic carbon is due to the presence of soil nitrogen in the organic forms (Verma et al., 1980). Similar results were also reported by Meena et al., (2006).

Available $\mathrm{P}_{2} \mathrm{O}_{5}$ in the soils samples varied from 42.00 to $212.70 \mathrm{~kg} \mathrm{ha}^{-1}$ (Table 1). Considering $20 \mathrm{kgha}^{-1}$ as critical limit for $\mathrm{P}_{2} \mathrm{O}_{5}$ deficient (Muhr et al., 1995), all the samples from the different polyhouses were sufficient in phosphorus. The available $\mathrm{P}$ in these soil samples was significantly and positively correlated with organic carbon $\left(\mathrm{r}=0.899^{* *}\right)$. Availability of phosphorus increased with increase in organic carbon due to (i) formation of phosphorus humic complexes which are easily assimilated by plants. (ii) anion replacement of phosphorus by humation and (iii) the coating of sesquioxide by particles of humus form a protective cover and thus reduced the phosphorus fixing capacity of the soils (Gharu and Tarafdar, 2004).

Available $\mathrm{K}_{2} \mathrm{O}$ content in soil samples varied from 135.40 to $503.00 \mathrm{~kg} \mathrm{ha}^{-1}$. None of the samples come under the deficient category of $\mathrm{K}$ with $125 \mathrm{~kg} \mathrm{ha}^{-1}$, as critical limit (Muhr et al., 1965). 
Table.1 Soil characteristics of different Polyhouses in Leh district

\begin{tabular}{|c|c|c|c|c|c|c|c|c|c|}
\hline \multirow[t]{2}{*}{ Location } & \multicolumn{3}{|c|}{ Chemical Properties } & \multicolumn{4}{|c|}{ Macronutrients } & \multicolumn{2}{|c|}{ Micronutrients } \\
\hline & $\begin{array}{c}\text { pH } \\
(1: 2)\end{array}$ & $\begin{array}{c}\mathrm{EC} \\
(\mu \mathrm{S} \\
\left.\mathrm{cm}^{-1}\right)\end{array}$ & $\begin{array}{l}\text { OC } \\
(\%)\end{array}$ & $\begin{array}{c}\mathrm{N} \\
\left(\mathrm{kg} \mathrm{ha}^{-1}\right)\end{array}$ & $\begin{array}{c}\mathrm{P}_{2} \mathrm{O}_{5} \\
\left(\mathrm{~kg} \mathrm{ha}^{-1}\right)\end{array}$ & $\begin{array}{c}\mathrm{K}_{2} \mathrm{O} \\
\left(\mathrm{kg} \mathrm{ha}^{-1}\right)\end{array}$ & $\begin{array}{c}\mathrm{S} \\
\left(\mathrm{mg} \mathrm{kg}^{-1}\right)\end{array}$ & $\begin{array}{c}\mathrm{Zn} \\
\left(\mathrm{mg} \mathrm{kg}^{-1}\right)\end{array}$ & $\begin{array}{c}\mathrm{Fe} \\
\left(\mathrm{mg} \mathrm{kg}^{-1}\right)\end{array}$ \\
\hline $\begin{array}{c}\text { Chinese } \\
\text { Greenhouse } 1\end{array}$ & 8.08 & 1073 & 1.19 & 345.1 & 203.7 & 218 & 231 & 2.12 & 5.93 \\
\hline $\begin{array}{c}\text { Chinese } \\
\text { Greenhouse } 2\end{array}$ & 8.45 & 1783 & 0.25 & 118.75 & 42 & 181.8 & 238 & 0.55 & 3.02 \\
\hline $\begin{array}{c}\text { Wooden } \\
\text { Greenhouse }\end{array}$ & 8.52 & 401 & 1.50 & 405 & 193 & 135.4 & 279 & traces & 7.16 \\
\hline Skuast 1 & 7.84 & 575 & 1.91 & 467.95 & 200.2 & 205.1 & 163 & traces & 9.07 \\
\hline LEHO & 8.42 & 395 & 0.76 & 266 & 153.7 & 277.3 & 50 & 1.85 & 7.05 \\
\hline LEHO Commercial & 8.39 & 417 & 1.33 & 365.75 & 193 & 203.8 & 129 & traces & 7.95 \\
\hline Walk-in-Tunnel 1 & 8.35 & 748 & 0.31 & 147.25 & 35.75 & 280.37 & 213 & 1.29 & 3.8 \\
\hline Walk-in-Tunnel 2 & 8.17 & 1293 & 1.25 & 362.5 & 185 & 424.4 & 209 & 0.37 & 7.72 \\
\hline $\begin{array}{c}\text { Walk-in-Tunnel } \\
\text { Large }\end{array}$ & 8.53 & 640 & 0.59 & 221.25 & 109 & 336.6 & 267 & traces & 5.48 \\
\hline Shade Net & 8.34 & 2730 & 1.75 & 437.5 & 212.7 & 503 & 282 & 0.74 & 9.52 \\
\hline Mud Wall 1 & 8.65 & 491 & 1.63 & 423.8 & 187.6 & 441.1 & 156 & 1.66 & 8.17 \\
\hline Mud Wall 2 & 7.93 & 1120 & 2.19 & 481.8 & 235 & 334.1 & 204 & 1.66 & 8.96 \\
\hline Local Greenhouse & 8.02 & 580 & 1.25 & 343.75 & 202.8 & 361.1 & 90 & traces & 9.29 \\
\hline $\begin{array}{c}\text { Local Green House } \\
\text { II }\end{array}$ & 8.06 & 987 & 1.23 & 356.7 & 186.7 & 371.5 & 176 & 0.18 & 9.74 \\
\hline Overall & 8.27 & 945 & 1.22 & 338.79 & 167.15 & 305.25 & 192 & 0.74 & 7.35 \\
\hline
\end{tabular}

Table.2 Correlations matrix

\begin{tabular}{|c|c|c|c|c|c|c|c|c|c|}
\hline \multicolumn{10}{|c|}{ Correlations Matrix } \\
\hline & $\mathrm{pH}$ & $\mathrm{EC}$ & $\mathrm{OC}$ & $\mathrm{N}$ & $\mathrm{P}$ & $\mathrm{K}$ & $\mathrm{S}$ & $\mathrm{Zn}$ & $\mathrm{Fe}$ \\
\hline pH & 1 & -.071 & -.447 & -.412 & -.444 & -.047 & .191 & .055 & -.460 \\
\hline EC & & 1 & .055 & .002 & -.021 & .401 & .531 & .066 & .004 \\
\hline OC & & & 1 & $.986^{* *}$ & $.899^{* *}$ & .439 & -.014 & .005 & $.829^{* *}$ \\
\hline $\mathbf{N}$ & & & & 1 & $.936^{* *}$ & .470 & -.048 & -.022 & $.864^{* *}$ \\
\hline $\mathbf{P}$ & & & & & 1 & .531 & -.168 & .007 & $.878^{* *}$ \\
\hline $\mathbf{K}$ & & & & & & 1 & -.047 & .001 & $.632^{*}$ \\
\hline $\mathbf{S}$ & & & & & & & 1 & -.134 & -.302 \\
\hline Zn & & & & & & & & 1 & -.195 \\
\hline $\mathbf{F e}$ & & & & & & & & & 1 \\
\hline
\end{tabular}


The $\mathrm{S}$ content in soil sample varied from 50 to $282 \mathrm{mg} \mathrm{kg}^{-1}$ with mean value $192 \mathrm{mg} \mathrm{kg}^{-1}$. Considering $10 \mathrm{mg} \mathrm{kg}^{-1}$ as critical limit for $\mathrm{S}$ deficiency (Tandon, 1992), none of the sample was deficient in S. Similar results were also reported by Jat and Yadav (2006), Sarkar et $a l,(2007)$ and Kaur and Jalali (2008).

The content of $\mathrm{Zn}$ in soil samples of the polyhouses varied from traces to $2.12 \mathrm{mg} \mathrm{kg}^{-1}$ with mean value of $0.74 \mathrm{mg} \mathrm{kg}^{-1}$. Considering $0.6 \mathrm{mg} \mathrm{kg}^{-1}$ as critical limit for $\mathrm{Zn}$ deficiency (Lindsay and Norvell, 1978), 57 percent of the sample was deficient in $\mathrm{Zn}$. Available $\mathrm{Fe}$ content in soil samples varied from 3.02 to 9.74 $\mathrm{mg} \mathrm{kg}^{-1}$ with an average value of $7.35 \mathrm{mg} \mathrm{kg}^{-1}$. Only 14 percent of the sample was deficient in available $\mathrm{Fe}$ with $4.5 \mathrm{mg} \mathrm{kg}^{-1}$ as critical limit (Lindsay and Norvell, 1978). The available Fe increased significantly with increase in organic carbon $(\mathrm{r}=0.829 * *)$.

The study concludes that soils of different poly houses at Precision Farming Development Centre (PFDC), SKUAST-K, in the cold arid region were rich inorganic carbon, available nitrogen, phosphorus, potassium, and Sulphur, Whereas majority of the soils were deficient in available $\mathrm{Zn}$ content. The present investigation gives information regarding the fertility status of soils of polyhouses, which shall help in the formulation of integrated nutrient management schedule for the better productivity of vegetables.

\section{References}

Chopra, S.L. and Kanwar, J.S. 1991. Analytical agricultural chemistry. Kalyani Publishers. New Delhi-Ludhiana, INDIA.

Gharu, Amita and Tarafdar, J.C. 2004. Influence of organic acids on mobilization of inorganic and organic phosphorus in soil. Journal of the Indian Society of Soil Science, 24: 248-253.

Jackson, M.L. 1973. Soil Chemical Analysis. Prentice Hall of India Pvt. Ltd., New Delhi.

Jat, J.R. and Yadav, B.L. 2006. Different forms of $S$ and their relationship with properties of Entisols of Jaipur district (Rajasthan) under Mustard cultivation. Journal of the Indian Society of Soil Science 54: 208-212.

Kaur, J. and Jalali, V.K. 2008. Forms of sulphur and their relationship in soil of different Agro-climatic zone of Jambu region. Journal of the Indian Society of Soil Science 56: 309-312.

Lindsay, W.L. and Norvell, W.A. 1978. Development of a DTPA soil test for zinc, iron, manganese, and copper. Soil Science Society America Journal 42, 421-428.

Meena, H.B., Sharma, P.R. and Rawat, U.S. 2006. Status of macronutirent in some soils of Tonk district of Rajasthan. Journal of the Indian Society of Soil Science 54: 205-512.

Muhr, G.R., Datta, N.P., Shanjkara, S.H., Laley, V.K. and Danahue. R.L. 1965. Soil testing in India, USDA publication, pp 120.

Sarkar, M., Ghosh, S.K., Mukhopadhyay, P. and Pal, S.K., 2007. Distribution of sulphur and its relationship with soil properties in some soil series (Alfisols) of West Bengal. Agropedology 17: 113-117.

Tandon. H.L.S. 1992. Fertilizer Guide Fertilizer Development and Consultation Organization, New Delhi.

Verma, L.P., Tripathi, B.R. and Sharma, D.P. 1980. Organics as an index to assess the nitrogen status of soils. Journal of the Indian Society of Soil Science 28:138-140.

Walkley, A. and Black, C.A. 1934. An examination method for determining soil organic matter and a proposed modifications of the chromic acid titration method. Soil Science 37: 29-38.

\section{How to cite this article:}

Phuntsog Tundup, Rigzin Sangdup Safal, D. Namgail, Sonam Spaldon, Anwar Hussain, Deldan Namgail and Yogesh Kumar. 2018. Soil Fertility Assessment under Different Polyhouses in Cold Arid Ladakh Region. Int.J.Curr.Microbiol.App.Sci. 7(02): 2135-2138.

doi: https://doi.org/10.20546/ijcmas.2018.702.255 